\title{
Human Values as a Predictor of Moral Maturity of Teacher Candidates
}

\author{
Dilek Yalız Solmaz \\ Faculty of Sport Sciences, Anadolu University, Eskisehir, Turkey
}

Copyright $\bigcirc 2018$ by authors, all rights reserved. Authors agree that this article remains permanently open access under the terms of the Creative Commons Attribution License 4.0 International License

\begin{abstract}
The aim of this study was to investigate the human values as a predictor of moral maturity of teacher candidates. The research group consists of 139 teacher candidates. "The Human Values Scale" and "The Moral Maturity Scale" are used as the data collection tool in the study. In the data analysis, "mean, standard deviation, Product-Moment Correlation coefficients and multiple regression" were used. As a result of the study, it has been observed that participant students' human values are above the average. Sub-dimensions of human values have been analyzed, freedom is considered as the most important value whereas materialistic values are considered as the least important. In the scope of this research, it has been analyzed that whether there is a relationship between human values and moral maturity level and it has been found that there is a significant positive relation between human values and moral maturity level. A multiple regression analysis was conducted to evaluate how well all-subscales of human values scores predicted moral maturity. The multiple correlation coefficient was .28, indicating that approximately $23 \%$ of the variance of the moral maturity can be accounted for by the linear combination of human values' subscales scores. It was seen that, "social values", one of the sub-dimensions of human values were reasonable predictors of moral maturity.
\end{abstract}

Keywords Human Values, Moral Maturity, Teacher Candidates, Physical Education and Sport

\section{Introduction}

Human beings, like other beings, continue living by fulfilling sets of requirements. These vital needs stand out as physical needs and biological needs. These conditions are valid for all kinds of beings; however, other conditions are required for human beings' existence. God has defined humankind as the most honorable living being on Earth and drawn attention to their superiority to other beings. These aspects are the values that are unique to humans [1]. The concept of value represents ideas such as something that is adopted, cherished, desired to be reached and realized, cared about; something good, right and beautiful [2]. The concept of value entering different disciplines and many theorists trying to explain the concept with various other concepts have made it difficult to define the concept of value.

Gutman [3] have defined values as principles that guide human behaviors and as a power that directs people in every period and aspect of their lives. The concept of values is frequently drawn upon to set light to the attitudes and behavior of individuals and the functioning of institutions, organizations, and societies [4]. According to Sherman [5], values guide our choices consciously or unconsciously, verbal or symbolically, and they are individual or social beliefs that form criteria for our cognitive, affective, behavioral judgments. In this sense, societies have power to influence values just as values influence societies. Through values, individuals' perspective is shaped, societies remain together and continuity of culture is maintained [6].

Individuals organize their lives according to their adopted value system. Values are behavioral patterns that make individuals' lives easier and ensure their lives within the society. Protecting values that persist with the influence of history, and which are sustained by the influence of tradition, custom and belief, are effective in directing the lives of individuals in society and directing their lives [7].

Values are principles that affect and shape every aspect of individuals' lives. While values are used as motives, decision making and sanctions on individual basis, in society they are used in political and ideological choices, social judgment and adaptation in groups [8].

Like values, another element that affects individuals' behavior in society and shape their life-style, is morality. Because value judgment is vital principle, it is also a moral concept. Just like value, the foundation of the concept of morality is also people [9]. Human behavior, whether is positive or negative, can be estimated through moral standards. Morality can also be considered as science of 
ideal rules that control people's behaviors and as an art that applies these rules to different aspects of life [10].

Moral sense does not come naturally, instead it is socially constructed. First impressions on behaviors and information about them are formed by reactions of other people, and these impressions and information shape moral conduct and moral principles [11].

Moral concepts are developed by passing through different phases. Distinguishing right from wrong, choosing the right one and put that into use is not a qualification that can be easily earned. Moral maturity implies being competent in terms of conscience, thoughts, judgment, attitude and behavior, and giving the richest, the best and necessary meaning to all these qualifications. An individual with moral maturity is expected to be reliable, responsible, respectful, fair, able to control himself/herself, able to empathize, a good person, and beyond all, a law-abiding citizen [12].

Moral maturity requires internalizing, placing moral values, and having a radical place in conscience. To reach moral maturity, emotions, ideas and judgment as moral values are not enough by themselves. Also, it requires thought-behavior consistency in order to transform these values into behavioral awareness. All these turning into moral habit creates moral maturity [13].

Social ethics and values that individuals have, affect their attitudes and behaviors, interactions with people, hence their world-view. Education is one of the most important institutions in terms of transferring moral and human values to individuals. Without doubt, education is the most important factor in the adoption of human values and moral development of individuals and societies. Teachers, who work in this field, are irreplaceable elements of the system because they contribute in developing and changing students' behaviors. It has been stated that in the concept of education, teachers affect students and shape their behaviors. For this reason, it can be thought that teachers' values and morality can also affect students. Also, there are studies showing the effects of teachers' behavior on students' behavior [14-15].

When examining the international and national literature, many researchers conducted studies in the recent years on determining human values. A large number of relational studies were made in this direction. The topics of the related studies are the link between human values and the various variables (gender, age, grades). The studies were made on different pupils of different education levels specially higher education levels [16-17-18-19-20-21-22].

Moreover, analyzing literature, there are many studies taken moral maturity [23-24-25-26-27-28-29] within different variables (gender, profession, age, education).

In this sense, possessed moral sentiment and favored values are important for prospective teachers, who study Physical Education and Sport Teaching departments. In this case, considering the fact that teacher candidates are teachers of the future; teaching profession coming up as a role model for students reveals that teacher candidates' human value perception level should be detected and relation to moral maturity should be determined.

\subsection{Research Questions}

The aim of this study was to investigate the human values as a predictor of moral maturity of teacher candidates. Within this framework, answers are sought for the questions as follows.

1- What are the levels of human values of teacher candidates?

2- What are the levels of moral maturity of teacher candidates?

3- Is there a significant correlation between teacher candidates' human values and moral maturity?

4- Are the sub-dimensions of human values a predictor of moral maturity?

\section{Materials and Methods}

\subsection{Participants}

One hundred and thirty nine students from first, second, third and fourth grades of Anadolu University, Department of Physical Education and Sports Teacher Training participated in this study. The data were gathered during 2014-2015 Academic Year. 48.9\% of the students in the study population were female, $51.1 \%$ are male. According to the grade levels, it is observed that students are $1^{\text {st }}$ class of $23.7 \%, 2^{\text {nd }}$ class of $28.1 \%, 3^{\text {rd }}$ class of $27.3 \%$ and $4^{\text {th }}$ class of $20.9 \%$.

\subsection{Data Collection Tools}

Data were collected by means of "The Moral Maturity Scale" which was originally developed by Şengün and Kaya [13] and "The Human Values Scale" which was originally developed by Dilmaç and Arıcak [30].

The Human Values Scale: The Human Values Scale is a ten-point Likert scale instrument with nine subsections (Social Values (10 items), Career Values (5 items), Intellectual Values (6 items), Spritual Values (4 items), Materialistic Values (3 items), Honor of Humanity (3 items), Romantic Values ( 3 items), Freedom (3 items) and Futuwwat/munificience \& courage (2 items)). Students are required to rate themselves between 0 (it does not matter) to 9 (very important) points for each item. The validity and reliability of the original instrument was tested by Dilmaç and Arıcak [30]. The Cronbach's alpha internal consistency coefficient of the scale containing 39 items and nine sub-dimensions was calculated to be Social Values to .90 , Career Values to .80, Intellectual Values to .78, Spritual Values to .81, Materialistic Values to .78, Honor of Humanity to .61, Romantic Values to .66, Freedom 
to .65 and Futuwwat/munificience $\&$ courage to .63 . In this study, consequence of repeated analysis of the reliability of whole scale is determined ".91". Also, the nine sub-dimensions is determined Social Values to .86, Career Values to .70, Intellectual Values to .73, Spritual Values to .79, Materialistic Values to .70, Honor of Humanity to .60, Romantic Values to .70, Freedom to .60 and Futuwwat/munificience \& courage to .65., respectively. Since this value is a higher than ".70" standard which is adequate for research, it was concluded that that scale can be used in research as a whole [31].

The Moral Maturity Scale: The Moral Maturity Scale is a five-point Likert scale instrument with one-dimension. Students are required to rate themselves between 1 to 5 points for each item ("yes, every time $=5$ ", "most of the time $=4$ ", "occasionally= 3", "very rare=2", "no, never=1") There are 52 positive and 14 negative statements. The validity and reliability of the original instrument was tested by Şengün and Kaya [13]. The Cronbach's alpha internal consistency coefficient of the scale containing 66 items was calculated to be ".93". In this study, consequence of repeated analysis of the reliability of whole scale is determined ".94". Since this value is a higher than ".70" standard which is adequate for research, it was concluded that that scale can be used in research as a whole [31].

\subsection{Analysis}

After implementing as planned the data collection tool used in the study of students, responses to scale have been reviewed individually by the researcher. There were a few scales left unmarked or left blank. They were left outside the scope of the assessment. Before beginning the analysis of data related to the study of statistical methods to determine compliance with the SPSS program have analyzed the distribution of the data, the distribution of the kurtosis and skewness were studied. Even though in the literature there are no standard values certain accepted, when the normal skewness and kurtosis values are \pm 2 and \pm 7 intervals, Chou and Bentler [32] and Curan, West and Finch [33] stated they show normal distributions. A normal distribution is a cluster that each of which may be defined by a mean and standard deviation of the distribution. When students' The Human Values Scale and The Moral Maturity Scale scores are analyzed in terms of kurtosis and skewness, Chou and Bentler [32] and Curan, West and Finch [33] stated that the kurtosis and skewness of the data showed a normal distribution according to the values they said (see to Table 1). After analysis of the distribution of data, of the tests to be used in order to decide whether the examined homogeneous (Levene $>0.05$ ), it is determined that the data are homogeneous. In the data analysis, "mean, standard deviation, Product-Moment Correlation coefficients and Multiple regression" were used. Product-Moment Correlation coefficients were calculated in order to see the relationship between the sub-dimensions of human values and the scores related to moral maturity. Multiple regression analysis was performed in order to determine the capacity of values for explaining and predicting the moral maturity.

\section{Results}

Tables which are showing about opinions of students participating on research's findings are given below.

Table 1. The level of the students' human values and moral maturity

\begin{tabular}{|c|c|c|c|c|c|c|c|}
\hline & $\mathrm{N}$ & Mean & $\mathrm{Sd}$ & Skewness & $\begin{array}{c}\text { Skewness Std. } \\
\text { Error }\end{array}$ & Kurtosis & $\begin{array}{c}\text { Kurtosis } \\
\text { Std. Error }\end{array}$ \\
\hline Social Values & 139 & 8.23 & .79 & -1.279 & .206 & 1.667 & .408 \\
\hline Career Values & 139 & 7.89 & 1.04 & -.955 & .206 & .168 & .408 \\
\hline Intellectual Values & 139 & 8.08 & .98 & -1.999 & .206 & 2.554 & .408 \\
\hline Spiritual Values & 139 & 7.12 & 1.87 & -.969 & .206 & .227 & .408 \\
\hline Materialistic Values & 139 & 6.48 & 1.78 & -.708 & .206 & .577 & .408 \\
\hline Honor of Humanity & 139 & 8.26 & 1.14 & -2.039 & .206 & 2.459 & .408 \\
\hline Romantic Values & 139 & 6.74 & 1.83 & -1.104 & .206 & 1.423 & .408 \\
\hline $\begin{array}{c}\text { Freedom } \\
\text { Futuwwat \& courage }\end{array}$ & 139 & 8.34 & .90 & -2.102 & .206 & 2.137 & .408 \\
\hline $\begin{array}{c}\text { Human Values Total } \\
\text { Score }\end{array}$ & 139 & 7.93 & 1.25 & -1.410 & .206 & 1.853 & .408 \\
\hline $\begin{array}{c}\text { Moral Maturity Total } \\
\text { Score }\end{array}$ & 139 & 7.80 & .80 & -.991 & .206 & 1.012 & .408 \\
\hline
\end{tabular}


Table 2. Correlations between sub-dimensions of human values and moral maturity

\begin{tabular}{|c|c|c|c|c|c|c|c|c|c|c|c|}
\hline & 1 & 2 & 3 & 4 & 5 & 6 & 7 & 8 & 9 & 10 & 11 \\
\hline Social Values & 1 & & & & & & & & & \\
\hline Career Values & $.661^{* *}$ & 1 & & & & & & & & & \\
\hline Intellectual Values & $.528^{* *}$ & $.716^{* *}$ & 1 & & & & & & & & \\
\hline Spiritual Values & $.560^{* *}$ & $.458^{* *}$ & $.440^{* *}$ & 1 & & & & & & & \\
\hline Materialistic Values & $.255^{* *}$ & $.437^{* *}$ & $.237^{* *}$ & $.274^{* *}$ & 1 & & & & & & \\
\hline Honor of Humanity & $.586^{* *}$ & $.500^{* *}$ & $.444^{* *}$ & $.632^{* *}$ & $.294^{* *}$ & 1 & & & & & \\
\hline Romantic Values & $.228^{* *}$ & $.276^{* *}$ & $.305^{* *}$ & $.274^{* *}$ & $.308^{* *}$ & $.308^{* *}$ & 1 & & & & \\
\hline Freedom & $.373^{* *}$ & $.493^{* *}$ & $.504^{* *}$ & $.224^{* *}$ & $.172^{*}$ & $.202^{*}$ & $.256^{* *}$ & 1 & & & \\
\hline Futuwwat \& courage & $.344^{* *}$ & $.341^{* *}$ & $.486^{* *}$ & $.372^{* *}$ & .032 & .141 & $.226^{* *}$ & $.379^{* *}$ & & 1 & \\
\hline Human Values Total Score & $.799^{* *}$ & $.820^{* *}$ & $.766^{* *}$ & $.749^{* *}$ & $.520^{* *}$ & $.705^{* *}$ & $.526^{* *}$ & $.535^{* *}$ & $.494^{* *}$ & 1 & \multicolumn{1}{|c|}{1} \\
\hline Moral Maturity Total Score & $.441^{* *}$ & $.398^{* *}$ & $.340^{* *}$ & $.356^{* *}$ & .033 & $.314^{* *}$ & .057 & $.317^{* *}$ & $.188^{*}$ & $.417^{* *}$ & 1 \\
\hline
\end{tabular}

$* \mathrm{p}<.05 ; * * \mathrm{p}<.01$

Table 3. Effect on the moral maturity of the human values

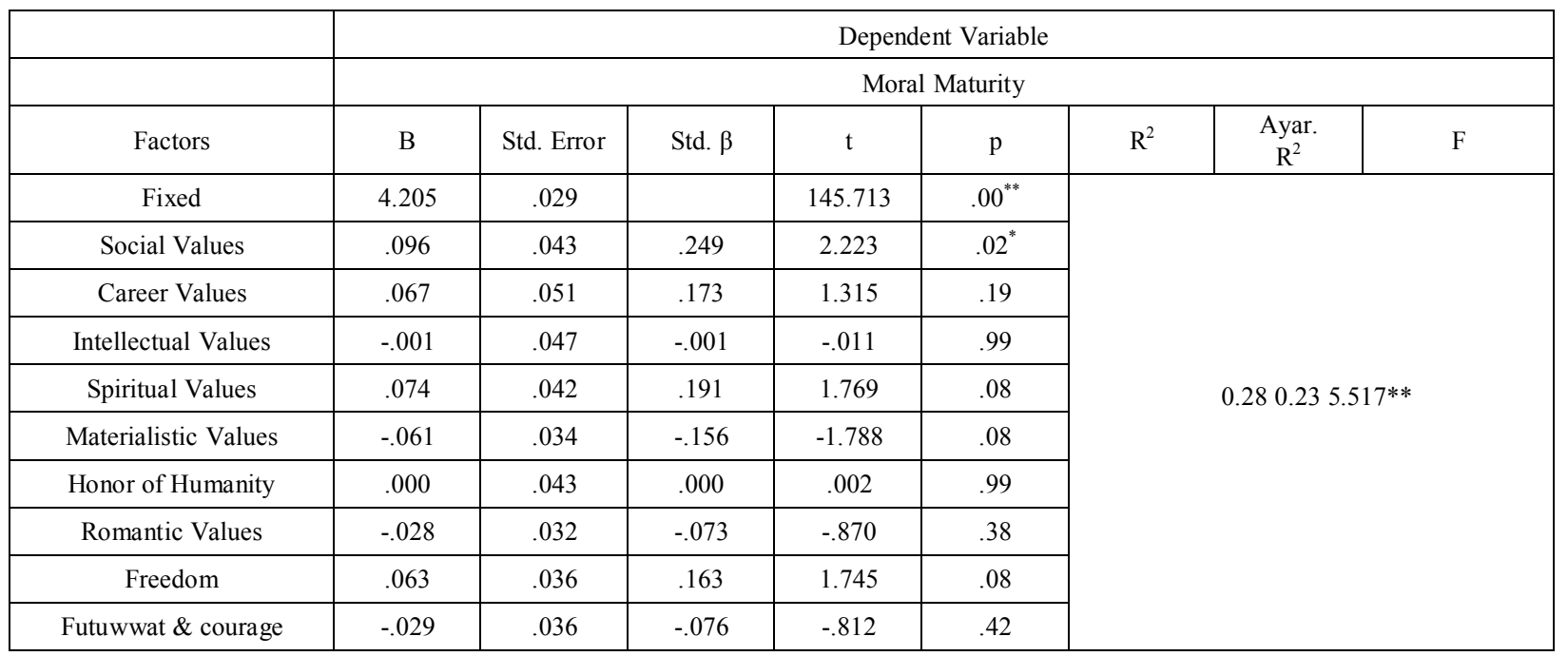

$* \mathrm{p}<.05 ; * * \mathrm{p}<.01$

Table 1 shows that the students' human values total score $(\mathrm{M}=7.80)$, was slightly above the average score of the scale. It is observed that the students had high-level average values in all sub-dimensions in human value perceptions. The highest value perception of students was determined in Freedom Values with $\mathrm{M}=8.34$; and the lowest value perception was determined in Materialistic Values sub-dimension with $\mathrm{M}=6.48$. Table 1 shows that the students' moral maturity total score $(\mathrm{M}=4.20)$, was slightly the high score of the scale.

In order to determine the relationship between participant's moral maturity level and human values, Pearson Correlation analysis has been applied. As shown Table 2, in the research, correlation coefficients of human values and moral maturity level varies between $\mathrm{r}=.033$ and $\mathrm{r}=.441$. When examining Table 2 , it has been observed that there is a positive relationship between human values and moral maturity, with .01 significance level $(\mathrm{r}=.417)$. When correlation values between moral maturity and sub-dimensions of human values are examined, it is observed that the highest correlation is between social values $(\mathrm{r}=.441 ; \mathrm{p}<.01)$ and moral maturity. It has been found out that there is a positive and significant relationship between career value $(\mathrm{r}=.398, \mathrm{p}<.01)$, spiritual value $(\mathrm{r}=.356, \mathrm{p}<.01)$, intellectual value $(\mathrm{r}=.340, \mathrm{p}<.01)$, freedom $(\mathrm{r}=.317, \mathrm{p}<.01)$, honor of humanity $(\mathrm{r}=.314$, $\mathrm{p}<.01)$, futuwwat $(\mathrm{r}=.188, \mathrm{p}<.05)$ from another dimensions of human values, and moral maturity. It has also been found out that there is a positive yet no significant relationship between moral maturity and materialistic $(\mathrm{r}=.033, \mathrm{p}>.01)$ and romantic values $(\mathrm{r}=.057, \mathrm{p}>.01)$.

In order to see the explanatory effect of human values on moral maturity; multiple regression analysis has been applied. The results are shown in the Table 3 .

In Table 3, it has been revealed that there is a low level of significant difference in sub-dimensions of human values and moral maturity $\left(\mathrm{R}=.28, \mathrm{R}^{2}=.23, \mathrm{p}<.01\right)$. The results of regression model, has shown that the regression 
model is statistically significant $(\mathrm{F}(9,129)=5.517 ; \mathrm{p}<0.01)$ and explained $23 \%$ of all dependent variables called sub-factors of moral maturity. When the t-test results of regression coefficients' significance have been analysed, it has been observed that only social values are important predictor on moral maturity $(\beta=.249, \mathrm{p}=0,02)$. Other variables do not have significant effect on the subject.

\section{Discussion}

This study was aim to investigate the human values as a predictor of moral maturity of teacher candidates. The results were as follows:

It has been observed that participant students' human values are above the average. This information reveals that students' human values are at good level. Sub-dimensions of human values have been analyzed, freedom is considered as the most important value whereas materialistic values are considered as the least important. In the study, it has been found out that freedom and honor of humanity are core values that shape the lives of the prospective teachers. On the other hand, they care materialistic values such as money, possessions, and status less.

The concept of freedom, which teacher candidates have remarked as the most important value, has been defined as a state that one can choose what they want, do or be able to act without being precluded or limited. The main goal of education is to raise individuals as free citizens. As general education, physical education also has an important role on individuals to be free. In other words, the basic function of physical education and sports is to ensure individuals to act freely [34]. Especially today, considering the fact that children cannot play freely on the streets for many reasons; it would not be wrong to say that activities such as physical education classes, which enable them to discharge their energies and act freely, are very important for them. The most important task in this regard falls to physical education teachers. During physical education classes, in order for students to act freely, teachers should embrace the concept of freedom themselves first. Data collected from this research support this idea.

Another value that teacher candidates consider important is human dignity, which comes out as result of getting one's right [35]. Kaboğlu [36] has stated that freedom, equality, and human dignity are foundational concepts and elements of liberty and they are closely related to each other. According to him, without human dignity, freedom and equality cannot be established. Human dignity is the common base of freedom and equality. Internalizing the concept of human dignity forms the driving force of creating equal and liberal citizens [36]. Besides, protecting exemption of human dignity as a constitutional right shows how these values are important for individuals. Value of human dignity involving not only physical education teachers but also all citizens, supports all data that has been suggested in this research.

Findings from this research are supported by several researchers. One of these studies was conducted in 2009 by Coşkun and Yıldırım. On his study regarding university students' value judgment level, Coşkun and Yıldırım [16] has stated that university students' value level is quite high. Also, Bacanl1 [37] has stated that university students care about first individual then social values; whereas, they do not care about being authoritative or rich in the society. Keskin and Sağlam [17] has stated that form teacher candidates care more about human dignity and freedom; and consider romantic and materialistic values less important. As the results have indicated, teacher candidates' choices support the view of this research's values of freedom, human dignity, and social values. In his study, Firat [18] has indicated that one of the most important values that teachers care is self-direction, which includes freedom. According to Dilmaç et al. [19], prospective teaches consider universality, security, kindness and self-direction as the most important values. In his research on high school students' attitude towards values, Ulusoy [20] have also reached similar results and it has been observed that students have positive attitudes and views towards issues such as embracing human values, being fair, having positive thoughts on their own societies and humanity, not seeking profit from everything, being self-sacrificing, hospitality, learning that oppressing is a bad behavior. Moreover, results of Calp's [21] similar study on high school students have shown that young individuals have high tendency in contributing in social and individual values. According to Sarıc1 Bulut's [22] research, values such as being rich, being appreciated by other people, being authoritative, pleasure; which are among the least preferred values in his research, shows parallelism with the values such as career, romance, and materialistic values; which are among the least preferred values in this research.

Another result obtained from this research is that teacher candidates' moral maturity level is also quite high. According to this result, it can be said that teacher candidates' moral maturity are at good level. Considering the fact that teachers play an important role on students' education, teacher candidates' high moral maturity can be seen as a positive sign.

These findings obtained from the research are supported by several researchers. One of these researches has been conducted by Çekin [23]. In his research on determining teacher candidate's moral maturity level, Çekin [23] has found out that teacher candidates have high level of moral maturity. Yüksel [24] has conducted a similar research on elementary school teachers and as a result he found out that elementary school teachers have high level of moral maturity. Şengün [25] has conducted a research on high school students aiming analyzing the students' moral maturity levels with various variables, and has found out 
that high school students have moderate level of moral maturity.

In the scope of this research, it has been analyzed that whether there is a relationship between human values and moral maturity level and it has been found that there is a significant positive relation between human values and moral maturity level. When correlation values between moral maturity and sub-dimensions of human values are examined, it is observed that the highest correlation is between social values and moral maturity. It has been found out that there is a positive and significant relationship between career value, spiritual value, intellectual value, freedom, honor of humanity, futuwwat from another dimensions of human values, and moral maturity. Besides, it has been observed that there is a positive but no significant relationship between moral maturity and materialistic values and romance values. According to Kohlberg (1969), in order for individuals to reach moral maturity in traditional level, they need to acquire rules and values themselves or from the society. In this sense, it can be said that moral maturity contains human values [1]. In his study on relationship between human values and moral maturity in adolescents, Sarıçam et al. [1] has found out that there is a positive relationship between moral maturity and all dimensions of human values. As a result of practice, which aims to educate $4^{\text {th }}$ and $5^{\text {th }}$ grade students about human values and examine the effectiveness of this practice with moral maturity scale, Dilmaç [38] has observed that there is an improvement in moral maturity level of the students who have participated in human values education program. These results support the significant relationship between human values and moral maturity, which have been obtained from the research.

Besides, according to another result of the study, among sub-dimensions of human values, only social values dimension could explain $23 \%$ of total variance of moral maturity. This result shows that social values are important predictors on moral maturity. Other variables (spritual values, career values, freedom, materialistic values, futuwwat \& courage, romantic values, intellectual values and honor of humanity) do not have an important impact. All these results indicate that among human values, only social values are related to moral maturity. Moral development is a process that aims individuals to create their value judgment and principles, and adopt the environment they live in, by embracing the social values. In other words, individuals' improving their moral values depends on adopting social values. In a society, social values connect individuals to each other. Social values also affect individuals' moral judgment. Individuals' moral judgment reflects the characteristics of the social system in their society. In a sense, moral behavior of individuals is reflection of the society [39]. However, no study could be found on the subject in order to support this interpretation.

\section{Conclusions}

In conclusion, along with many other qualifications on the field, teaching is a profession that should represent moral maturity behaviors. Teachers are considered as prominent people in the society and are always in the public eye. Teachers, who expect children and young people to have moral values, should have these values first and set an example for them. Besides, considering the findings of the research on the effects of teachers' values on students [14-40-15-41], it is essential for teachers to behave the way they want children to behave.

In this study, it was researched whether the human values are a predictor of the moral maturity of the teacher candidates. As a result, it has been seen that, "social values", one of the sub-dimensions of human values were reasonable predictors of moral maturity.

Finally, this study has some limitations. These limitations are that the sample group consists only of physical education teacher candidates and is limited to a university. Descriptive studies can be done by expanding the sample group in the future researches. In addition, according to the results that will come out of that study, experimental studies that will increase the human values and moral maturity for teacher candidates can be made.

\section{REFERENCES}

[1] H. Sarıçam, I. Çelik, N. Arıcı, M.M. Kaya. The examination of relationship between human values and moral maturity in adolescence, International Journal of Human Sciences (IJHS), Vol. 11, No. 1, pp. 1325-1342, 2014.

[2] M. Şişman. Organizations and Cultures, Pegem Akademi, Ankara, 2011.

[3] J. Gutman. A means-end chain model based on consumer categorization processes, Journal of Marketing, Vol. 46, no. 2, pp. 60-72, 1982.

[4] S.H. Schwartz, G. Melech, A. Lehmann, S. Burgess, M. Harris, V. Owens. Extending the cross-cultural validity of the theory of basic human values with a different method of measurement, Journal of Cross-Cultural Psychology, Vol. 32, pp. 519-542, 2001.

[5] S.M. Shearman. Culture, Values, and Cultural Variability: Hofstede, Inglehart, and Schwartz's Approach, The Annual Convention of the International Communication Association, Montreal, QC, Canada, 2008.

[6] Ü. Sığrı, A. Tabak, Ü. Ercan. The evaluation of cultural values from the aspect of managament: Turkish banking sector study, Organizasyon ve Yönetim Bilimleri Dergisi, Vol. 1, No. 2, pp. 1-14, 2009.

[7] R. Özkan. Some thoughts on teacher qualifications, Bilim ve Aklın Aydınlığında Education Journal, Vol. 5, No. 58, pp. 46-50, 2004.

[8] E. Özensel. The sociological relevance of values, Journal of 
Values Education, Vol. 1, No. 3, pp. 217-239, 2003.

[9] S. Turan, D. Aktan. Existing and ideal social values of school life as perceived by teachers and students, Journal of Turkish Educational Sciences, Vol. 6, No. 2, pp. 227-259, 2008

[10] M. Kaya, C. Aydın. The investigation relations between religious belief and moral maturity levels of students at university, Ondokuz Mayss University Review of The Faculty of Divinity, Vol. 30, pp. 15-40, 2011.

[11] T. Altınköprü. Çocuğun Başarısı Nasıl Sağlanır, Hayat Publishing, İstanbul, 1999.

[12] T. Lickona. Educating for Character: How Our Schools Can Teach Respect and Responsibility, Bantam Books, New York, 1991

[13] M. Şengün, M. Kaya.. The scale of moral maturity: the study of its validity and reliability, Ondokuz Mayıs University Review of The Faculty of Divinity, Vol. 24-25, pp. 51-64, 2007.

[14] J. Brophy, T. Good. Teacher behaviour and student achievement, In: M Wittrock (Eds.), Handbook of Research On Teaching, Macmillan, New York, 1986.

[15] D.J. Dickinson. The relation between ratings of teacher performance and student learning, Contemporary Educational Psychology, Vol. 15, No. 2, pp. 142-152, 1990.

[16] Y. Coşkun, A. Yıldırım. Examining the value levels of university students' in terms of some variables, Yüzüncü Y1l University Education Faculty Journal, Vol. 1, No. 6, pp. 311- 328, 2009.

[17] U. Keskin, H.İ. Sağlam. Examining the level of humanitarian values of class teacher candidates from different variables, Sakarya University Journal of Education, Vol. 4, No. 1, pp. 81-101, 2014.

[18] N. Firat. School culture and teachers' value systems, Ph. D. Thesis, Unpublished, Dokuz Eylül University, İzmir, 2007.

[19] B. Dilmaç, H. Bozgeyikli, Y. Çikili. The investigation of teacher candidates' value perceptions in terms of various variables, Journal of Values Education, Vol. 6, No. 16, pp. 69-91, 2008.

[20] K. Ulusoy. The assessment of student attitudes and views towards traditional and democratic values in the history programme of high school in terms of various variables, $\mathrm{Ph}$. D. Thesis, Unpublished, Gazi University, Ankara, 2007.

[21] Ö. Calp. Inspection of the view of high school last class students to the social values (Sample of Hatay Central County), Master Thesis, Unpublished, Gazi University, Ankara, 2006.

[22] S. Saric1 Bulut. Value tendencies of the students at the college of education of Gazi University, International Journal of Turkish Literature Culture Education, Vol. 1, No. 3, pp. 216-238, 2012.

[23] A. Çekin. Moral maturity level of teacher candidates, Kastamonu Education Journal, Vol. 21, No. 3, pp. 1035-1048, 2013.

[24] G. Yüksel. The relationship of elementary school teachers' competence beliefs in character education and their ethical maturity levels, Master Thesis, Unpublished, Osmangazi
University, Eskișehir, 2012.

[25] M. Şengün. The examination of moral maturity levels of high school students in terms of some individual variables, Ph. D. Thesis, Unpublished, Ondokuz Mayıs University, Samsun, 2008.

[26] A. Adigüzel. The relation between candidate teachers' moral maturity levels and their individual innovativeness characteristics: A case study of Harran University Education Faculty, Educational Research and Reviews, Vol. 7, No. 25, pp. 543-547, 2012.

[27] Y. Y1ldirım. Analysis of moral maturity levels and social attitudes of the 5th and 6th grades of secondary school, Master Thesis, Unpublished, Erzincan University, Erzincan, 2014.

[28] D. Hart, C. Gusto. Moral development in adolescence, Journal of Research on Adolescence, Vol. 15, No. 3, pp. 223-233, 2005.

[29] L.J. Walker. Sexism in Kohlberg's moral psychology? In W. M, Kurtines \& J. L. Gewirtz (Eds.), Moral development; An introduction (s. 83-107), Allyn \& Bacon, Boston, 1995.

[30] B. Dilmaç, O.T. Arıcak. The validity and reliability study of the scale of values, 2nd International Symposium on Values Education, İstanbul, 2012.

[31] Ş. Kalayci. SPSS Applied Multivariate Statistical Techniques, Asil Publishing, Ankara, 2008.

[32] C.P. Chou, P.M. Bentler. Estimates and Tests in Structural Equation Modelling. In: RH Hoyle (Eds.), Structural Equation Modelling: Concepts, Issues and Applications, Thousand Oaks, CA: Sage, 1995.

[33] P.J. Curan, S.G. West, J.F. Finch. The Robustness of test statistics to non-normality and specification error in confirmatory factor analysis, Psychological Methods, Vol. 1, No. 1, pp. 16-29, 1996.

[34] R.S. Kretchmar. Ten more reasons for quality physical education, Journal of Physical Education, Recreation \& Dance, Vol. 77, No. 9, pp. 6-9, 2006.

[35] A. Mercier. Foundations of Human Rights. In: I. Kuçuradi (Eds.), Philosophical Foundations of Human Rights, Türkiye Felsefe Kurumu, Ankara, 1996.

[36] İ.Ö. Kaboğlu. Freedom Law: An Essay on the Human Rights Legal Structure, AFA Publishing, İstanbul, 1994.

[37] H. Bacanl. Value preferences of university students, Educational Administration: Theory and Practice, Vol. 20, pp. 597-610, 1999.

[38] B. Dilmaç. Instruction human value program and evaluating it using moral maturity inventory, Master Thesis, Unpublished, Marmara University, İstanbul, 1999.

[39] G.K. Çırak. Moral judgement abilities of the university students and the comparison of their moral judgement abilities and their levels of self-realization, Master Thesis, Unpublished, Çukurova University, Adana, 2006.

[40] F.D. Gözütok. Democratic Attitudes of Prospective Teachers, Türk Demokrasi Vakfı Publishing, Ankara, 1995.

[41] A.S. Saracaloğlu. 21. Yüzylda öğretmen adaylarının nitelikleri, Atatürk ve Cumhuriyete Armağan, Vol. 1, pp 253-290, 2006. 